\title{
Üst gastrointestinal sistem endoskopisinde saptanan çift ektopik pankreas dokusu
}

\author{
Double ectopic pankreatic tissue revealed at the upper gastrointestinal endoscopy
}

Firdevs TOPAL ${ }^{1}$, Sabiye AKBULUT ${ }^{2}$, Elif SARITAŞ YÜKSEL ${ }^{1}$, Nurullah ILHAN ${ }^{1}$, Fatih Esad TOPAL ${ }^{3}$

Izmir Katip Çelebi Üniversitesi, Atatürk Eğitim ve Araştırma Hastanesi, ${ }^{1}$ Gastroenteroloji Bilim Dal, ${ }^{3}$ Acil Tip Bilim Dall, Izmir, Türkiye

Sağllk Bilimleri Üniversitesi, Kartal Koşuyolu Yüksek Ihtisas Sağlı Uygulama ve Araştırma Merkezi, ${ }^{2}$ Gastroenteroloji Bilim Dall, Istanbul, Türkiye

55 yaşında, erkek hasta. Dispeptik yakınmaları nedeniyle üst gastrointestinal sistem (GIS) endoskopisi yapıldı. Mide atrumunda, polipoid görünümde ve üzeri normal mukoza ile kaplı, ortası çökük, etrafı kabarık, temiz yüzeyli $2 \times 3 \mathrm{~cm}$ çaplarında, yan yana duran, çift ektopik pankreas dokusu izlendi (Resim 1). Tanı amaçlı radyal endosonografi (EUS) yapıldı. Lezyonun 3.tabakadan (submukoza) kaynaklanması, eko paterninin heterojen olması, pankreas kanalının görülmesi (Resim 2) ile ektopik pankreas tanısı kondu.

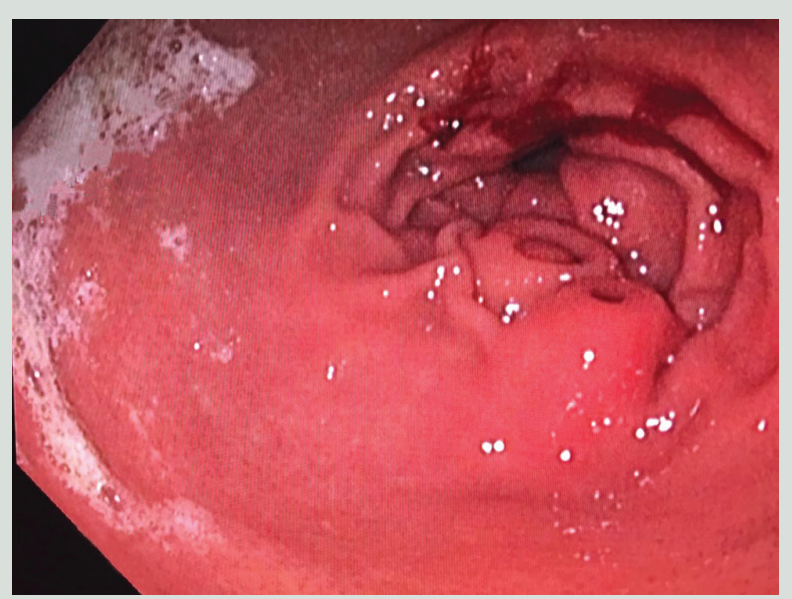

Resim 1. Mide antrumunda çift ektopik pankreasın gastroskopik görünümü.
Ektopik pankreas (EP), gastrointestinal sistemin herhangi bir lokalizasyonunda görülebilen konjenital bir anomalidir. Midede EP sık görülmeyen gastrik sumukozal lezyonlardır. Genellikle mide antrumunda, büyük kurvatur yerleşimli ve çoğunlukla asemptomatiktir. Üst GIS endoskopisi sırasında tesadüfen saptanırlar. Asemptomatik olmasına rağmen; bazen dispeptik yakınmalar, kanama, pankreatit ve kanser gelişimi ile kendini göstermektedir (1,2). Üst GIS'de tek EP olguları bildirilmiş olmakla birlikte; çift EP olgu sunumu oldukça nadirdir.

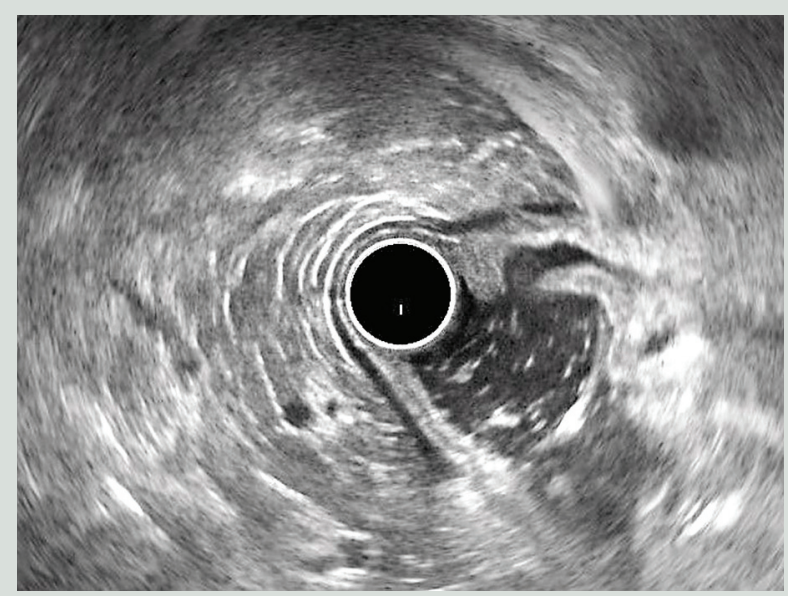

Resim 2. Mide antrumunda çift ektopik pankreasın endosonografik görünümü.

\section{KAYNAKLAR}

1. Uğur Kantar F, Akarsu M, Atılla K, et al. Ectopic pancreas presenting with intractable diarrhea: case report. Turk J Gastroenterol 2011;22:426-9.

Topal F, Akbulut S, Yüksel ES, et al. Double ectopic pankreatic tissue revealed at the upper gastrointestinal endoscopy. Endoscopy Gastrointestinal 2018;26:73.
2. Misheva B, Hajjar R, Chapdelaine H, et al. Ectopic jejunal pancreas with pancreatitis mistaken for a post-transplant lymphoproliferative disease in an immunosuppressed kidney transplant patient. J Surg Case Rep 2018;2018:ryj259. 